\title{
Change-over natural and mechanical ventilation system energy consumption in single-family buildings
}

\author{
Maria Kostka $^{1, *}$, and Matgorzata Szulgowska-Zgrzywa ${ }^{1}$ \\ ${ }^{1}$ Wrocław University of Science and Technology, Faculty of Environmental Engineering, Wybrzeze \\ Wyspiańskiego 27, 50-370 Wrocław, Poland
}

\begin{abstract}
The parameters of the outside air in Poland cause that in winter it is reasonable to use a mechanical ventilation equipped with a heat recovery exchanger. The time of spring, autumn, summer evenings and nights are often characterized by the parameters of the air, which allow for a natural ventilation and reduce the electricity consumption. The article presents the possibilities of energy consumption reduction for three energy standards of buildings located in Poland, ventilated by a change-over hybrid system. The analysis was prepared on the assumption that the air-to-water heat pump is the heat source for the buildings.
\end{abstract}

\section{Introduction}

\subsection{Residential ventilation solutions in Poland}

A typical ventilation in single-family buildings in Poland is implemented in one of two ways - natural/gravity or mechanical. In the natural system the driving force of the air exchange is the pressure difference on the building partition, caused by the difference of internal and external temperature and by the wind. This is the basic system used over many years in the Polish construction industry. Along with the change of regulations related to the quality of buildings, their thermal insulation improvement and energy demand reduction, the currently used mechanical systems are becoming popular. This type of ventilation in detached buildings reduces the energy consumption needed in the natural system for heating the outdoor infiltration air rate. The air exchange is provided by two fans placed in the air handling unit (AHU), equipped also with an exhaust air heat recovery exchanger, air filters and a heater. Usage of the heat recovery is crucial and justifies the choice of the mechanical systems. In case of the gravity ventilation used in low-energy buildings, cost of outdoor air heating become a significant operating cost [1]. Mechanical ventilation allows reducing the cost of ventilation and ensures the constant air exchange efficiency, which is not possible in the case of natural ventilation in the Polish climate. Fluctuations of the outside air temperature in Poland cause that the efficiency of natural ventilation is variable during the year. In winter the volume of the exchanged air is higher

*Corresponding author: maria.kostka@pwr.edu.pl 
than during the rest of the year and the reason is the large difference between the internal and external temperatures. It has a significant impact on the energy demand and the building heating costs. In the warmer periods of the year, when the temperature differences decrease, the efficiency of the natural system is also getting lower. It may also happen that the air exchange ceases completely.

The parameters of outside air in Poland indicate that a combination of the mechanical and the natural ventilation in detached buildings can be cost-effective and allow keeping the thermal comfort and good indoor air quality. Low temperatures in winter cause that it is reasonable to use mechanical ventilation equipped with a heat recovery from the exhaust air. Also during summer, in case of a high outside temperature and days of windless weather, the use of fans and a heat recovery system is justified because it maintains a proper air exchange in the building and reduces overheating of the interiors. The time of spring, autumn, summer evenings and nights are often characterized by the parameters of air, which allow for the natural building ventilation. The combination of the natural and the mechanical systems is realized by the hybrid ventilation.

\subsection{Hybrid ventilation}

The hybrid ventilation is only a general name of system which combines the natural and the mechanical processes, but does not define the forms of control strategy. Their common operation can be implemented in a variety of ways: seasonal switching, switching as a result of a measured parameter (e.g. outside air temperature, indoor temperature, indoor $\mathrm{CO}_{2}$ concentration) or simultaneous work of systems. In the professional literature, there is lack of information about the design of such systems. There are also very few examples of existing solutions and their energy efficiency. The hybrid ventilation in residential constructions was conducted by M. Kim and J. Hwang [2]. According to their definition, the system with a mechanical air exhaust and a natural air supply is classified as a hybrid system. For an apartment located in Seoul they attempted to determine the airflow which provides comfortable thermal conditions and good air quality, also taking into account the energy savings. A similar system with a mechanical exhaust was studied by D. Jreijiry, A. Husaunndee and C. Inrad [3]. They developed hybrid system control strategies for the housing sector. For buildings located in Greece and France their research conducted that a hybrid ventilation system enables decrease of more than $50 \%$ of the exposure of the occupants to high concentrations of $\mathrm{CO}_{2}$ while reducing at the same time the electrical energy consumed by the fan by $90 \%$. K. Miachou and all [4] conducted a comparative study of natural and hybrid systems for dwellings located in Athens. They showed a slight advantage of the natural system in the air exchange. Their research has been performed in the framework of the research project RESHYVENT [5]. This program defined the design objectives for hybrid ventilation systems and outlined the solutions proposed by the four industrial and scientific consortia for four different European climates zones.

\subsection{The justification of the topic}

According to the report of Central Statistical Office of Poland, the percentage share of households in the energy consumption structure occupied the first place in 2014 and exceeded $30 \%$ [6]. On a national scale, with the construction of approximately 70,000 new single-family buildings each year, solutions that combine natural and mechanical ventilation can provide significant reductions in the energy needs. Due to the differences between the countries that have taken up the research topic earlier, including climatic conditions, typical building structures or even residents' expectations, the results of the research should not be directly applied to Poland. For this reason, there is a need to assess 
the energy potential of the hybrid systems operating in the temperate climate of our country.

\section{Climate in the selected cities}

Poland is located in the temperate climate zone, in the transitional area between the temperate oceanic climate on the west and the temperate continental climate on the east. Due to the influence of the continental and oceanic air masses, as well as the direct influence of the Baltic Sea and the presence of mountain areas, the parameters of the outside air in Poland are various in the different regions of the country. The assessment of the energy potential of hybrid ventilation systems should therefore be conducted on a case-by-case basis rather than being generalized to the national results.

Figure 1 show the hourly average outside air parameters for 3 selected Polish cities located in the different regions of the country: Suwałki (influence of the continental air masses), Gdańsk (influence of the Baltic Sea) and Wrocław (temperate region). Figure 2 shows the duration of the outside air temperature for this locations.
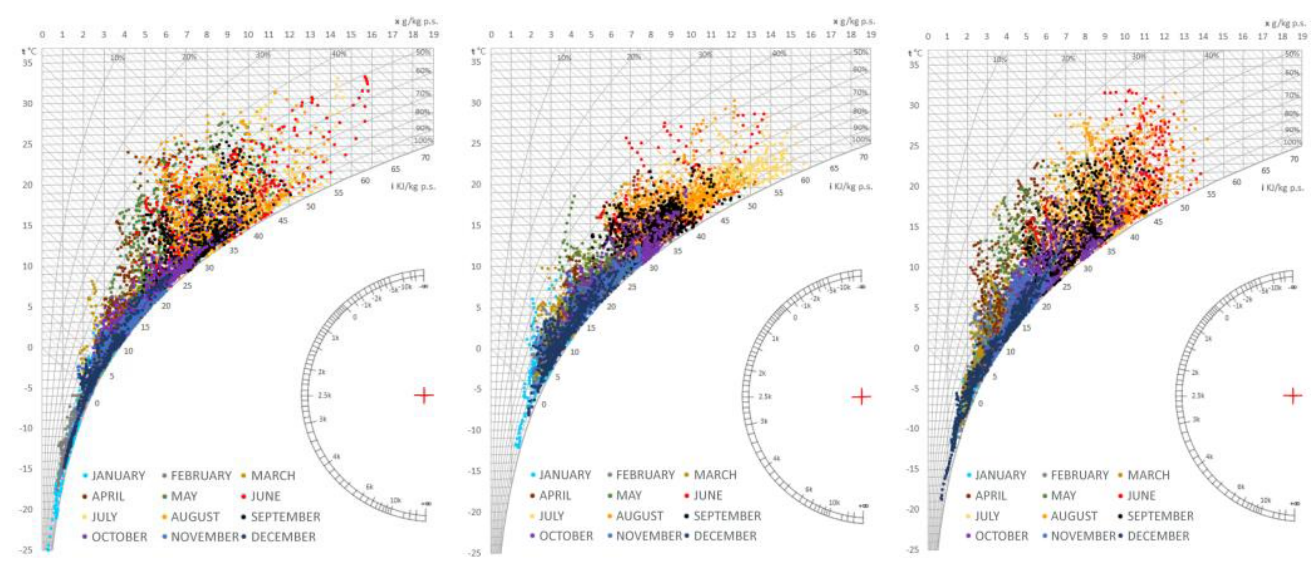

Fig. 1. The parameters of outside air - Suwałki (left), Gdańsk (center), Wrocław (right).

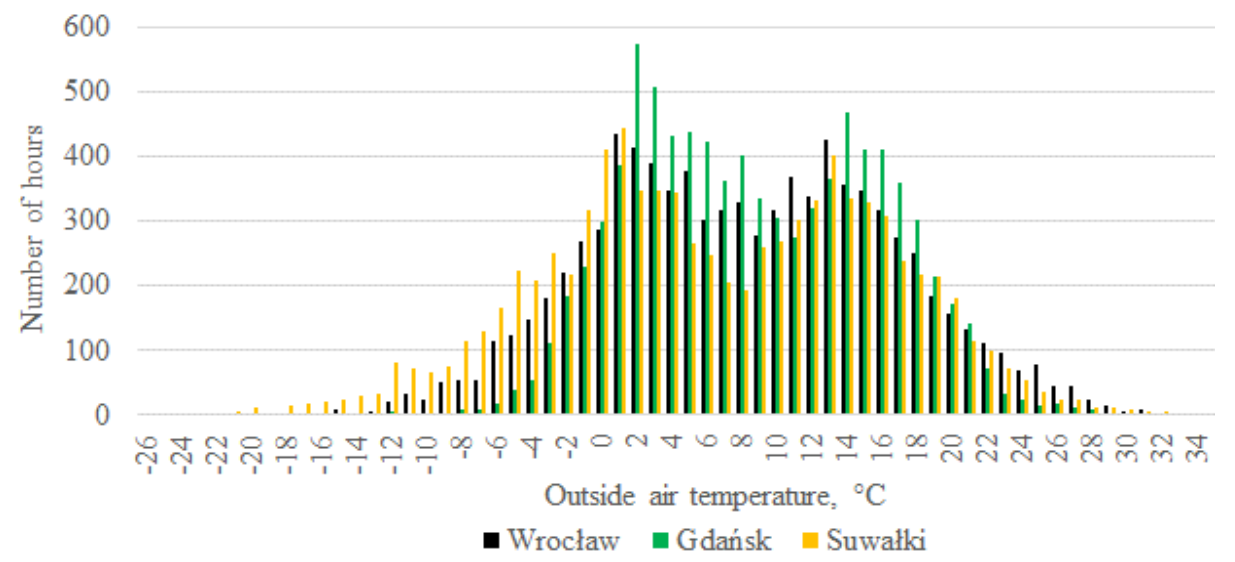

Fig. 2. The duration of the outside air temperature. 
According to the presented meteorological data [7], Gdańsk is characterized by the mildest parameters of the outdoor air. Temperatures in the range of $1-20^{\circ} \mathrm{C}$ occurs there for about $85 \%$ of the year, while in Wroclaw about $75 \%$, and in Suwałki only about $66 \%$ of the year. Wroclaw has the highest number of hours with temperatures above $20^{\circ} \mathrm{C}$ - over $7 \%$ of the year, while in Suwałki it is about 5\% and in Gdańsk less than 4\%. The longest duration of the temperature $0^{\circ} \mathrm{C}$ and less occurs in Suwałki - about $29 \%$ of the year. In Wrockaw it is about $18 \%$, and in Gdańsk only about $11 \%$. Demonstrated differences indicate a higher climate potential for the hybrid system in the areas characterized by a mild climate. In these locations, the longer the time of the natural ventilation system usage the lower the energy savings associated with the mechanical ventilation work is expected.

\section{The research problem}

The article presents the energy benefits of using a hybrid ventilation system instead of a full-year mechanical ventilation with the heat recovery. The analysis was performed for a single-family building with a usable area of $160 \mathrm{~m}^{2}$. The ventilation air flow rate is $250 \mathrm{~m}^{3} / \mathrm{h}$, which corresponds to a building air change rate $\mathrm{ACH}=0.5 \mathrm{~h}^{-1}$. The first step of the calculations was to analyse the work of the building in the variant with the mechanical ventilation with the heat recovery $(M W)$. The reason for this is that the heat recovery is an essential element that increases the energy efficiency of a building. Then, for the hybrid ventilation $(H W)$, the energy savings potential of the final energy demand for the building's heating was determined. In this case the hybrid ventilation was implemented as temporary switching from the mechanical ventilation $(M W)$ to the natural system $(N W)$. The decision to switch between the ventilation systems in the applied algorithm is based on the total final energy consumption of the building. It is defined further below, in Table 3. The analysis was performed for the climatic data presented in point 2 of this article. The heat source in the analysed case was an air-to-water heat pump.

\subsection{Building energy class}

As a result of the increase of the energy efficiency requirements, the demand for usable energy for heating the newly designed single-family houses in Poland is decreasing. An analysis of the hybrid ventilation impact on the building's energy efficiency has been carried out on three variants of a detached house, described by the building's heat losses because of the transmission $\left(Q_{t r}\right)$. These variants are: a standard building B9 $\left(Q_{t r}=9 \mathrm{~kW}\right)$, a low energy building B6 $\left(Q_{t r}=6 \mathrm{~kW}\right)$ and an ultra-low energy building B3 $\left(Q_{t r}=3 \mathrm{~kW}\right)$. The standard building is the one whose heat transfer coefficients meet the minimum requirements for single-family houses in Poland and the usable energy index for heating $(E U)$ is c.a. $100 \mathrm{kWh} /\left(\mathrm{m}^{2}\right.$ year $)$. The low-energy building is the one in which the heat transfer coefficients guarantee that the $E U$ index is smaller than $40 \mathrm{kWh} /\left(\mathrm{m}^{2} \cdot\right.$ year $)$. The ultra-low-energy building requires the $E U$ index at about $15 \mathrm{kWh} /\left(\mathrm{m}^{2} \cdot\right.$ year $)$. Table 1 summarizes the buildings' heat losses by transmission $\left(Q_{t r}\right)$ and the usable energy indexes $(E U)$ for the three variants of the building energy classes in different climate conditions. 
Table 1. The static heat losses and the usable energy index.

\begin{tabular}{|c|c|c|c|c|c|c|}
\hline & \multicolumn{2}{|c|}{ Gdańsk } & \multicolumn{2}{|c|}{ Wroclaw } & \multicolumn{2}{|c|}{ Suwałki } \\
\hline$\underset{k W}{Q_{t r}}$ & $\begin{array}{c}E U_{N W} \\
\mathrm{kWh} /\left(\mathrm{m}^{2} \text { year }\right)\end{array}$ & $\begin{array}{c}E U_{M W} \\
\mathrm{kWh} /\left(\mathrm{m}^{2} \text { year }\right)\end{array}$ & $\begin{array}{c}E U_{N W} \\
\mathrm{kWh} /\left(\mathrm{m}^{2} \text { year }\right)\end{array}$ & $\begin{array}{c}E U_{M W} \\
\mathrm{kWh} /\left(\mathrm{m}^{2} \text { year }\right)\end{array}$ & $\begin{array}{c}E U_{N W} \\
\mathrm{kWh} /\left(\mathrm{m}^{2} \text { year }\right)\end{array}$ & $\begin{array}{c}E U_{M W} \\
\mathrm{kWh} /\left(\mathrm{m}^{2} \text { year }\right)\end{array}$ \\
\hline 9 & 88 & 61 & 97 & 67 & 122 & 85 \\
\hline 6 & 61 & 36 & 68 & 40 & 87 & 51 \\
\hline 3 & 36 & 13 & 41 & 15 & 53 & 19 \\
\hline
\end{tabular}

\subsection{Mechanical ventilation system}

The air volume for the mechanical ventilation system is $250 \mathrm{~m}^{3} / \mathrm{h}$. Figure 3 shows the configuration of the air handling unit (AHU). The AHU is assumed in the cross-counter flow heat exchanger with the $80 \%$ efficiency. The frost protection of the heat exchanger is an electric preheater, operated when the temperature of the exhaust air (measured by the sensor $\mathrm{T}_{\mathrm{e}}$ ) drops below $5^{\circ} \mathrm{C}$ and at the same time outside air temperature is below $0^{\circ} \mathrm{C}$. The supply air temperature is controlled by an electric heater to a temperature $\mathrm{T}_{\mathrm{s}}=16^{\circ} \mathrm{C}$. The heaters work with the fluent regulation of power. The electrical power of the fans is $160 \mathrm{~W}$.

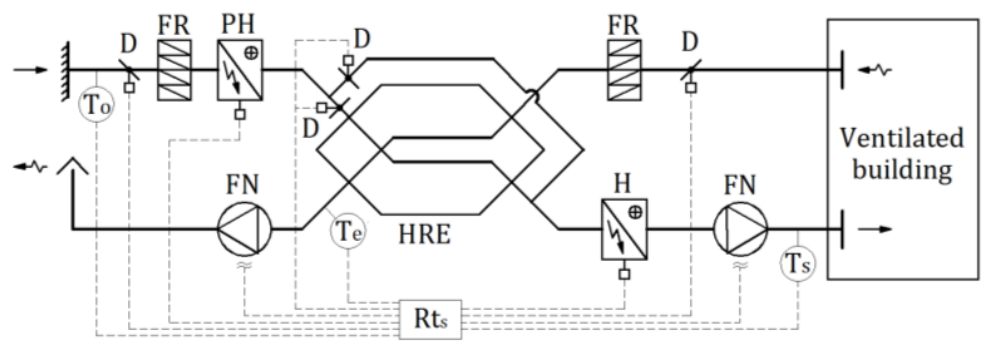

Fig. 3. AHU configuration (D - damper, FR - filter, FN - fan, HRE - heat recovery exchanger, $\mathrm{PH}$ - preheater, $\mathrm{H}$ - heater, $\mathrm{T}_{\mathrm{o}}$ - outside air temperature sensor, $\mathrm{T}_{\mathrm{s}}-$ supply air temperature sensor, $\mathrm{T}_{\mathrm{e}}-$ exhaust air temperature sensor, $\mathrm{Rt}_{\mathrm{s}}-$ supply air temperature regulator).

\subsection{Heating system}

The calculations were made on the assumption that the building is heated by an air-to-water heat pump. Selection of the heat pump in each of the analyzed variations was based on the thermal characteristics of the building equipped with the mechanical ventilation system with a heat recovery exchanger. In each of the climatic zones and for each building energy class, the power of the pump was chosen so that the bivalent point was $-10^{\circ} \mathrm{C}$. Table 2 shows the heat pomp COP data for the heating water supply temperature $35^{\circ} \mathrm{C}$ and $45^{\circ} \mathrm{C}$. The analysis assumes that the building is equipped with an underfloor heating with the parameters of heating agent $40 / 30^{\circ} \mathrm{C}$. The minimum outdoor air temperature required to the heat pump is $\mathrm{T}_{\mathrm{a}}=-15^{\circ} \mathrm{C}$.

Table 2. The COP of the heat pump for the heating water supply temperature $35^{\circ} \mathrm{C}$ and $45^{\circ} \mathrm{C}$.

\begin{tabular}{|c|c|c|c|c|c|c|c|}
\hline $\mathbf{T}_{\mathbf{a}},{ }^{\mathbf{}} \mathbf{C}$ & $\mathbf{- 1 5}$ & $\mathbf{- 7}$ & $\mathbf{2}$ & $\mathbf{7}$ & $\mathbf{1 0}$ & $\mathbf{1 2}$ & $\mathbf{2 0}$ \\
\hline COP for $35^{\circ} \mathrm{C}$ & 1.89 & 2.62 & 3.25 & 4.29 & 4.40 & 4.63 & 5.29 \\
\hline COP for $45^{\circ} \mathrm{C}$ & 1.50 & 2.10 & 2.80 & 3.10 & 3.40 & 3.50 & 4.10 \\
\hline
\end{tabular}




\subsection{Methods of calculations}

The simulations in this article were made in hourly steps based on the climate data described in point 2. The total final energy demand for the buildings with the natural ventilation as well as with the mechanical ventilation with the heat recovery were calculated. The total final energy demand for the building with the natural ventilation comes from the electricity required to run the heat pump for the building's heating $\left(Q_{H P, N W}\right)$. The total final energy demand for the building with the mechanical ventilation comes from the electricity required to run the heat pump for the building's heating $\left(Q_{H P, M W}\right)$ and the electricity required for the central air supply (the power for the fans and the electric preheater - $\left.Q_{E L, M W}\right)$. The electricity demand for the operation of the air-to-water heat pump for heating the building was determined based on the seasonal coefficient of the performance (SCOP). The SCOP of the air-to-water heat pump was calculated taking into account the partial load correction of the equipment and the operation in the stand-by mode. The steps of the calculations were described in the Table 3. For the building with the hybrid ventilation, the decision in which ventilation system $(N W$ or $M W)$ it should be operating was based on the comparison of the total final energy consumption for both solutions $\left(Q_{K, N W}\right)$ and $\left(Q_{K, H W}\right)$ in every hour. Next, the share of the working time of the ventilation system with the heat recovery $\left(\tau_{M W}\right)$ and the savings results from the use of the hybrid ventilation, both the quantitative $\left(\Delta Q_{H W}\right)$ and the percentage $\left(\beta_{H W}\right)$, were calculated.

Table 3. The steps of the analysis.

\begin{tabular}{|c|c|c|c|}
\hline \multirow{2}{*}{ The ventilation system } & $\begin{array}{c}\text { Building with the } \\
\text { mechanical ventilation }\end{array}$ & \multicolumn{2}{|c|}{$\begin{array}{c}\text { Building with the } \\
\text { hybrid ventilation }\end{array}$} \\
\cline { 2 - 4 } & $M W$ & $N W$ & $M W$ \\
\hline $\begin{array}{c}\text { The total final energy } \\
\text { consumption of the building } \\
\text { calculated for each hour in } \\
\text { year (1-8760 h) }\end{array}$ & $\begin{array}{c}Q_{K, M W}= \\
Q_{H P, M W}+Q_{E L, M . W .}\end{array}$ & $Q_{H P, N W}$ & $Q_{H P, M W}+Q_{E L, M W}$ \\
\cline { 3 - 4 } & & $Q_{K, H W}=\min \left(Q_{H P, N W}, Q_{E L, M W}+Q_{H P, M W}\right)$ \\
\hline $\begin{array}{c}\text { The savings resulting from } \\
\text { the use of the hybrid } \\
\text { ventilation }\end{array}$ & - & $\begin{array}{c}\Delta Q_{H W}=\sum_{i}\left(Q_{H P, M W}+Q_{E L, M W-} Q_{H P, N W}\right) \\
\text { where: } i-\text { the hours in year when } \\
Q_{H P, N W}<\left(Q_{E L, M W}+Q_{H P, M W}\right)\end{array}$ \\
& & $\beta_{H . W .}=\Delta Q_{H . W} /\left(Q_{H P, M . W .}+Q_{E L, M . W}\right)$ \\
\hline
\end{tabular}

\section{Results}

The results of the analysis for all the variants are summarized in Table 4 . The following values were shown: the total final energy demand during the year for the building with the mechanical ventilation with the heat recovery $\left(Q_{H P, M W}\right.$ and $\left.Q_{E L, M W}\right)$, the savings results from the work of the hybrid ventilation system $\left(\Delta Q_{H . W}\right.$. and $\left.\beta_{H . W}\right)$ and the time of the work of the mechanical ventilation per year in percentage $\left(\tau_{M . W .}\right)$.

For the standard energy class (B9) building, the annual savings results due to the hybrid ventilation $\left(\beta_{H . W .}\right)$ are between $9 \%$ and $10 \%$. Quantitatively $\left(\Delta Q_{H . W .}\right)$, the highest savings were observed for Suwałki, $950 \mathrm{kWh}$ per year. Because in this location the total final energy demand for the heat pump and the ventilation unit is the highest, the share of the energy saving is the smallest. For the low energy class (B6) building, the annual energy savings $\left(\beta_{H W}\right)$ range from $13 \%$ to $15 \%$. These savings are quantitatively slightly higher than in the standard building (B9). For the ultra-low energy class (B3) building, the annual energy savings $\left(\beta_{H W}\right)$ are between $18 \%$ and $28 \%$. Although the amount of the energy savings is lower than in other energy standards, the savings potential is the highest in these buildings. 
Table 4. The results of the analysis.

\begin{tabular}{|c|c|c|c|c|c|}
\hline \multirow{2}{*}{ The climate data } & QHР,мw & QEL,MW & $\Delta \mathbf{Q H W}_{\mathrm{H}}$ & $\tau_{\mathrm{MW}}$ & $\beta_{\text {но }}$ \\
\hline & $\mathrm{kWh} /$ year & $\mathrm{kWh} /$ year & $\mathrm{kWh} /$ year & $\%$ & $\%$ \\
\hline Building B9-Suwałki & 7496 & 2983 & 950 & $38 \%$ & $9 \%$ \\
\hline Building B9 - Wrocław & 5934 & 2172 & 677 & $47 \%$ & $8 \%$ \\
\hline Building B9 - Gdańsk & 5210 & 1805 & 727 & $46 \%$ & $10 \%$ \\
\hline Building B6 - Suwałki & 4591 & 2983 & 961 & $37 \%$ & $13 \%$ \\
\hline Building B6 - Wrocław & 3572 & 2172 & 708 & $46 \%$ & $12 \%$ \\
\hline Building B6 - Gdańsk & 3116 & 1805 & 762 & $45 \%$ & $15 \%$ \\
\hline Building B3 Suwałki & 1773 & 2983 & 852 & $44 \%$ & $18 \%$ \\
\hline Building B3 - Wrocław & 1341 & 2172 & 791 & $45 \%$ & $23 \%$ \\
\hline Building B3 - Gdańsk & 1140 & 1805 & 817 & $42 \%$ & $28 \%$ \\
\hline
\end{tabular}

In addition to the annual total final energy demand, it is interesting to discuss the monthly statistics of the potential savings in the total final energy demand due to using the hybrid ventilation instead of the full-year mechanical ventilation. These results are summarized in Figure 4.
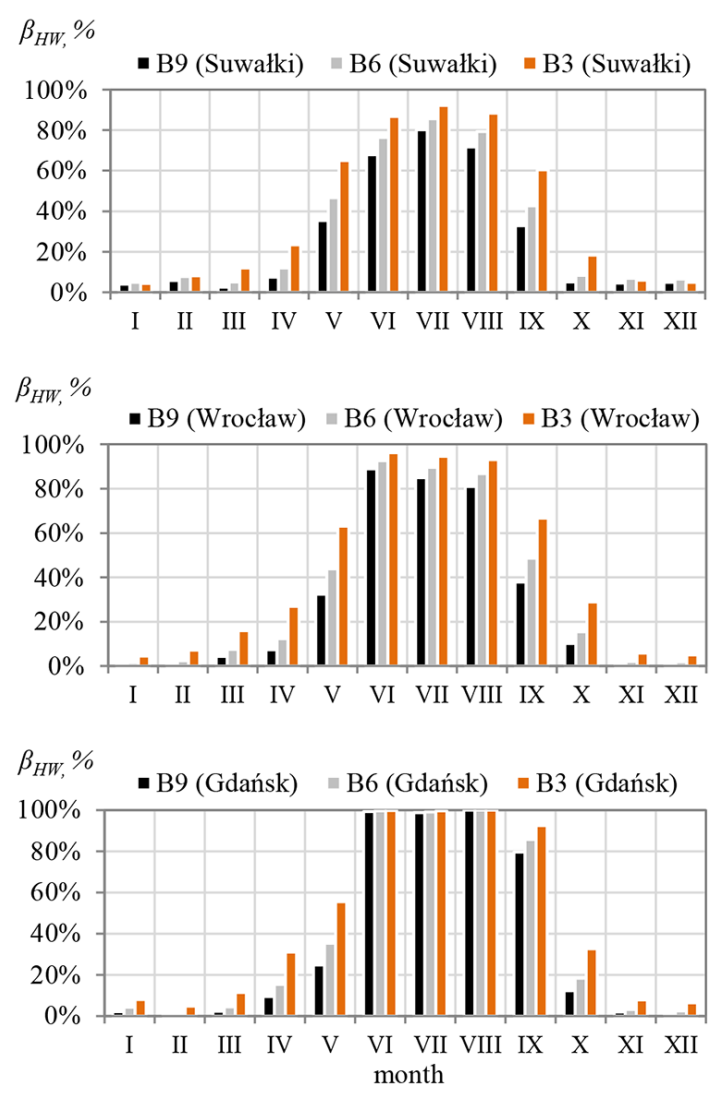

Fig. 4. The reduction in the finally energy demand in the building as a result of the hybrid ventilation.

In the winter months, the savings resulting $\left(\beta_{H W}\right)$ from the periodical shutdown of the mechanical ventilation are low. The percentages of these savings are the highest in Suwałki 
(up to $4 \%$ ), which results from the energy consumption in the protection system for the heat recovery exchanger before the frost. It is also clear that these savings are even higher when the building has a better energy class. During the transition periods III-V and IX-X the savings resulting $\left(\beta_{H W}\right)$ from the switching between the mechanical and the natural ventilation are already significant. For the ultra-low-energy building (B3) in the months $\mathrm{V}$ and IX, the savings $\left(\beta_{H W}\right)$ up to $60 \%$ comparing to the system with the continuous mechanical ventilation were found. In summer, the natural ventilation is a better system. In Gdansk, it would be advisable to completely shut off the mechanical ventilation system. In Wroclaw and in Suwałki the natural ventilation allows for a significant reduction in energy demand (from $65 \%$ to $95 \%$ ), although the ventilation unit work is periodically profitable.

\section{Conclusions}

Single-family buildings represent a large share of the residential market in Poland and they are impacting significantly the energy consumption in Poland. The climate in Poland varies in the different regions and the systems which are sensitive to the change of the ambient air temperature require the individual analysis. An example of such a system is the mechanical ventilation which periodically can be more costly than the natural ventilation. A detailed analysis of the energy effectiveness of using the hybrid ventilation (i.e. the periodic replacement of the mechanical ventilation by the natural ventilation) can only be carried out together with an analysis of the heating system and for the specific location of the building.

In this study, the analysis of the ventilation system operation was carried out in cooperation with an air-to-water heat pump. Both systems are very sensitive to the ambient air temperature data and in this case the impact of climate data on the system efficiency is particularly important. The significant potential of the energy savings in the total final energy demand (for the building's heating system) has been demonstrated for all the analyzed climates. It should be noted that the tendencies in the construction industry, enforced by the legal regulations, are that the buildings will have better and better energy classes, and the air-to-water heat pumps will become more and more popular in Poland. The presented analysis showed that the lower the demand for the usable energy for heating, the greater the effect of introducing the hybrid ventilation.

From a practical point of view, the analytical and research work are needed to develop both the technical solutions and the control algorithms for the hybrid ventilation systems in the single-family buildings.

\section{Acknowledgments}

This work is supported by funds from the Ministry of Higher Education for research and development works of young scientists and doctoral students. Project number: 0402/0098/16.

\section{References}

1. M. Kostka, M. Szulgowska-Zgrzywa, Rynek Instalacyjny, 3 (2016)

2. M. Kim, J. Hwang, Energ. Buildings 41, 579-586 (2009)

3. D. Jreijiry, A. Husaunndee, C. Inard, Sol. Energy 81, 227-239 (2007)

4. K. Niachou, S. Hassid, M. Santamouris, I. Livanda, Energ. Buildings 37, 503-513 (2005) 
5. RESHYVENT, Cluster Project on Demand Controlled Hybrid Ventilation in Residential Buildings with Specific Emphasis of the Integration of Renewables, European Joule Project, Contract No. ENK6-CT2001-00533 (2002)

6. http://stat.gov.pl/en/topics/environment-energy/energy/energy-efficiency-in-poland-inyears-2004-2014,5,12.html [access: 21.03.2017]

7. http://mib.gov.pl/2-Wskazniki_emisji_wartosci_opalowe_paliwa.htm\# [access: 01.2017] 